\title{
Revisional notes on the genus Melucha (Hemiptera, Heteroptera, Coreidae)
}

\author{
Harry Brailovsky ${ }^{1, \dagger} \&$ Ernesto Barrera ${ }^{1, \ddagger}$ \\ 1 Departamento de Zoología, Instituto de Biología UNAM, Apdo Postal 70153, México D.F. 04510 \\ † http://zoobank.org/29629435-7C6E-4F81-ADA3-CDE8B6E7001C \\ ‡ http://zoobank.org/CA3D495E-4EA4-4C42-B9F8-A62452606A5C \\ http://zoobank.org/C7480D90-8829-42F5-97B4-F2392F622E3E
}

Corresponding author: Harry Brailovsky (coreidae@ib.unam.mx)

\begin{abstract}
Received 15 January 2014

Accepted 03 April 2014

Published 30 May 2014

Academic editor:

Dávid Rédei
\end{abstract}

\section{Key Words}

Insecta

Hemiptera

Heteroptera

Coreidae

Nematopodini

Melucha

new species

new synonym

Neotropical

\section{Introduction}

The genus Melucha Amyot \& Serville, 1843, is distributed in Mexico, Central America (Guatemala, Costa Rica) and South America (Colombia, French Guiana, Brazil, Paraguay, Bolivia, Peru). It belongs to the tribe Nematopodini of the family Coreidae and is characterized by having: postocular tubercles not evident, forming a smooth curve with eye; antenniferous tubercles wide, not projecting far anteriorly; tylus projecting anteriorly of antenniferous tubercle; antennal segment I longer than length of head, thicker than following segments and curved; segment II cylindrical, III cylindrical or dilated, and IV fusiform; anterolateral and posterolateral borders of pronotal disk smooth or conspicuously nodulose and spinate; mesosternum lacking sulcation; and abdominal spiracles rather large, transversely elliptical, situated nearer to anterior than to lateral margins (O'Shea 1980).

The genus currently includes 11 species considered as valid: M. aculeata Montandon, 1895, M. acutispina Breddin, 1903, M. bicolor Distant, 1892, M. biolleyi Distant, 1900, M. chapadana Brailovsky, 1993, M. dilatata (Fabricius, 1798), M. gladiator (Fabricius, 1803), M. lineatella (Fabricius, 1803), M. phyllocnemis (Bur- 
meister, 1835), M. quinquelineata Stål, 1865, and $M$. ruficornis Breddin, 1903 (Brailovsky 1993, Packauskas 2010). In this contribution, M. quadrivittis Stål, 1862, is resurrected from synonymy under M. phyllocnemis and considered a valid species; M. ruficornis Breddin, 1903 is synonymized under $M$. lineatella (Fabricius). Two new species, $M$. grandicula sp. n. and M. perampla sp. n., are described from Bolivia, Colombia, Paraguay and Peru. New distributional records for M. phyllocnemis and $M$. quadrivittis are added. With these additions and changes the number of known species of Melucha is fixed in 13. A key to separate all the species of the genus is presented.

\section{Material and methods}

The following collection acronyms are used for the institutions cited in this paper:

AMNH American Museum of Natural History, New York, USA;

CDFA California State Collection of Arthropods, Sacramento, California, USA;

DEIC Deutsches Entomologisches Institut, Müncheberg, Germany;

INBIO Instituto Nacional de Biodiversidad, Santo Domingo de Heredia, Costa Rica;

MABR Museo Argentino de Ciencias Naturales "Bernardino Rivadavia”, Buenos Aires, Argentina;

MELN Museo Entomologico, Leon, Nicaragua;

NHMW Naturhistorisches Museum, Wien, Austria;

NHRS Naturhistoriska Riksmuseet, Stockholm, Sweden;

TAMU Texas A \& M University, College Station, Texas, USA;

UGAG University of Georgia, Athens, Georgia, USA;

UMSP University of Minnesota, Insect Collection, USA;

UNAM Instituto de Biología, Universidad Nacional Autónoma de México;

USNM Smithsonian Institution, National Museum of Natural History, Washington, DC, USA;

ZMUH Zoologisches Museum, Universität Hamburg, Hamburg, Germany.

All measurements are given in millimeters.

\section{Results}

\section{Melucha grandicula sp. $\mathbf{n}$.}

http://zoobank.org/3A82C0B5-2929-44C9-A97B-F5846317BFEC http://species-id.net/wiki/Melucha_grandicula

Fig. 11.

Type material. Holotype, female, Peru, Loreto, Headwaters, Río Loreto-Yacu, Indian Vill., 21-IV-1-V-1970, Malkin (AMNH). Paratypes, 1 female, Colombia, Meta, El Buque, silv., 1200 m, 18-II-1947 (NHMW); 1 female, Colombia, without date (UNAM).
Description (female, holotype). Dorsal color. Head and antennal segments I to III shiny orange, segment IV pale yellowish orange; pronotum coarsely punctate, strongly striate, reddish brown, with a single, longitudinal, median dark line, diffuse, with pigment in the punctures; scutellum reddish brown with basal third, lateral borders and apex shiny orange; clavus and corium finely punctate, reddish brown, moderately infuscate; hemelytral membrane amber, translucent, veins darker; connexival segments reddish brown with posterior spines black; dorsal abdominal segments dark orange with irregular dark marks.

Ventral color. Rostral segments (apex of IV dark brown), legs, and anterior and posterior lobe of metathoracic scent gland peritreme shiny to dull orange; pro- and mesopleura coarsely punctate with black elongate mark; hind femur dull orange with dorsal and ventral tubercles and spines black; hind tibiae dark orange with posterior third yellowish orange; middle and hind tarsus yellowish orange.

Structure. Body large-sized (above $22.00 \mathrm{~mm}$ ), robust, almost glabrous.

Head. Antennal segment III cylindrical; rostrum reaching anterior margin of mesosternum.

Thorax. Pronotal disk declivent; anterolateral borders obliquely straight, nodulose, armed with five or six subacute spines; humeral angles prominent, laterally expanded, apically sharply pointed; posterolateral borders almost straight, nodulose, with three or four subacute spines; posterior border smooth, straight; callar region evident.

Legs. Fore and middle femora not incrassate; dorsal surface smooth, ventral surface distally armed; hind femur incrassate its dorsal surface with two rows of tubercles, ventral surface armed with two rows of spines increasing in size distally; fore and middle tibiae sub-cylindrical, unarmed, sulcate; inner and outer surfaces of hind tibiae markedly dilated; outer surface smooth, inner surface with short tubercles on the border.

Scutellum. Triangular, wider than long, transversely striate and punctate; apex subacute.

Abdomen. Posterior angle of abdominal segments III to VI armed with short but distinct spine.

Male. Unknown.

Measurements (holotype; mm). Total body length 27.50. Head length 2.28; width across eyes 2.98; interocular space 1.74 ; interocellar space 0.92 ; preocular distance 1.61; length of antennal segments: I, 6.15; II, 4.25; III, 3.80; IV, 7.60. Pronotal length 6.53; width across humeral angles 11.78. Scutellar length 3.19; width 3.57. Maximum width of abdomen 9.70 .

Differential diagnosis. This species is closely related to M. phyllocnemis and M. quadrivittis, which are also robust and larger than $23.00 \mathrm{~mm}$; the other species in the genus are slender and shorter than $20.00 \mathrm{~mm}$.

Melucha grandicula sp. $\mathrm{n}$. is distinguished by having a single median dark line on the pronotal disk, the humeral angles prominent, laterally expanded, and apically sharply pointed (Fig. 11) and connexival segment VII en- 


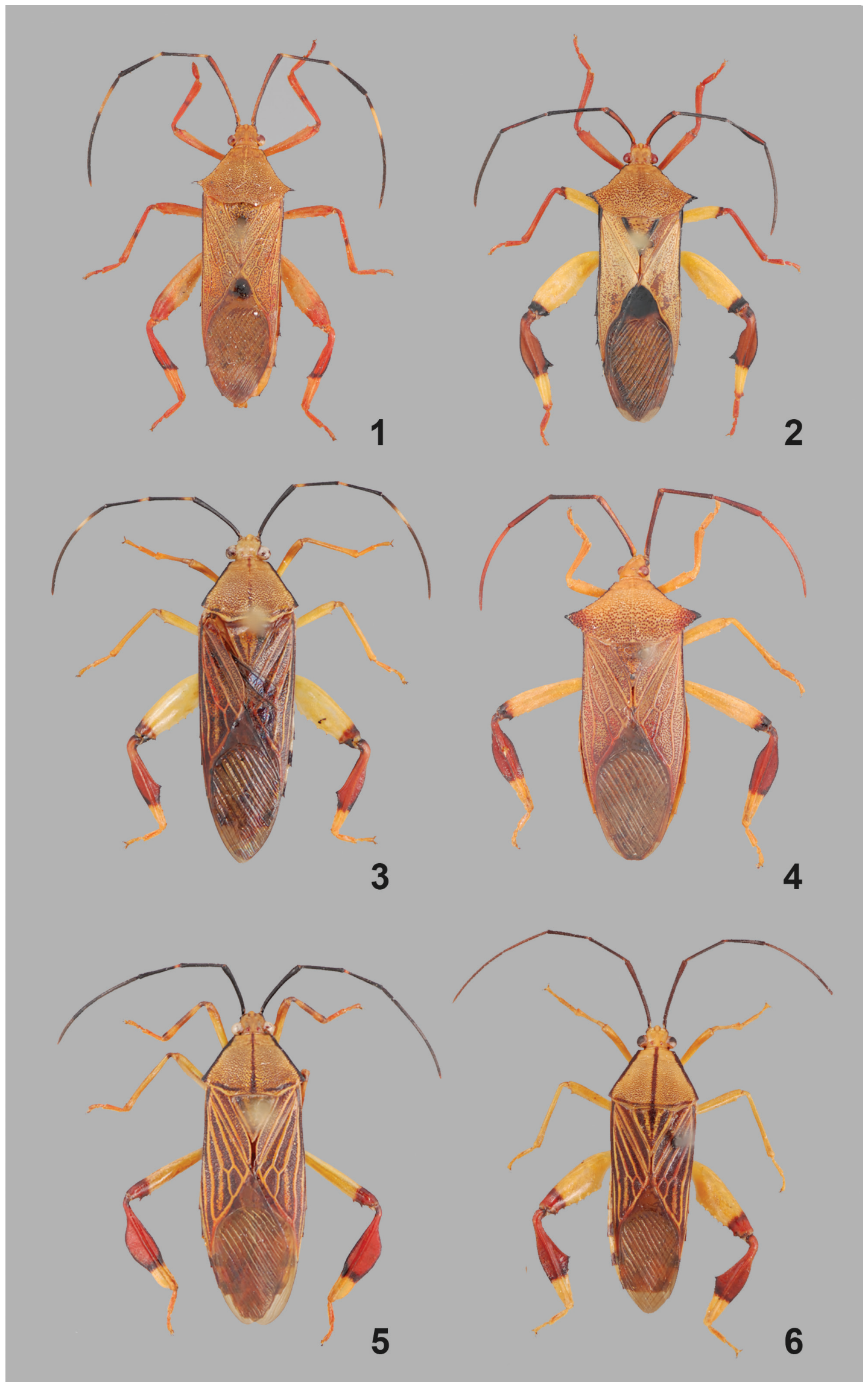

Figures 1-6. Dorsal view of Melucha spp. 1, M. aculeata Montandon, 1895 (male). 2, M. biolleyi Distant, 1900 (male). 3, M. dilatata (Fabricius, 1798) (male). 4, M. acutispina Breddin, 1903 (female). 5, M. chapadana Brailovsky, 1993 (female). 6, M. lineatella (Fabricius, 1798) (male). 
tirely dark orange. In the other two species the pronotal disk is yellow and has four longitudinal dark lines and the midline unpigmented, the humeral angles prominent, laterally expanded, and apically blunt (Figs. 8, 9) and connexival segment VII is yellow, with posterior half or posterior third dark brown.

Etymology. Named for the comparatively large size of this species, after the Latin adjective "grandiculus, $-a$, -um" meaning rather large.

Distribution. Known from Colombia and Peru.

\section{Melucha perampla sp. $\mathbf{n}$.}

http://zoobank.org/7FF2B7CC-BBA3-48A7-A251-894AE1C92AE8 http://species-id.net/wiki/Melucha_perampla Fig. 12.

Type material. Holotype: female, Bolivia, Departamento La Paz, Prov. Sud-Yungas, Puente Villa, 4300', 19-24-V1989, J. E. Eger (UNAM). Paratypes: 1 female, Paraguay, Cororo, X-1979, M. Viana (UNAM); 3 females, Departamento San Pedro, Cororo, Rio Ypane, 12-XI-1983, G. J. Williner (UNAM).

Description (female, holotype). Dorsal color. Head yellow; preocular area and two short, diffuse stripes laterally to midline pale brown; antennal segments I to III black, IV yellow; pronotum finely punctate, yellow, pronotal disk with four longitudinal dark brown lines with pigment in the punctures and midline unpigmented; anterolateral spines of pronotum reddish brown; scutellar disk yellow with punctures reddish brown; clavus and corium dark yellow with punctures reddish brown; hemelytral membrane dark amber, veins brown and darker; connexival segments III to $\mathrm{V}$ dark brown with anterior third yellow, VI-VII with anterior half yellow and posterior half dark brown, and VIII-IX yellowish orange; upper border of connexivum anteriorly yellow and posteriorly black; posterolateral spines black; dorsal abdominal segments dark yellow with irregular dark brown marks.

Ventral color. Rostral segments (apex of IV dark brown), legs, anterior and posterior lobe of metathoracic scent gland peritreme and abdominal sterna yellow; hind femur yellow with ventral spines and apical border reddish brown to black; hind tibia yellowish orange, posterior third yellow with dark reddish brown transverse mark near posterior third.

Structure. Body large-sized (above $22.00 \mathrm{~mm}$ ), robust, almost glabrous.

Head. Antennal segment III dilated; rostrum reaching anterior margin of mesosternum.

Thorax. Pronotal disk declivent; anterolateral borders obliquely straight, armed with 15 or more acute spines; humeral angles prominent, laterally expanded and apically blunt; posterolateral borders nodulose with three or four subacute spines; posterior border smooth, straight; callar region evident.

Legs. Fore and middle femora not incrassate their dorsal surface smooth, ventral surface distally armed; hind femur incrassate its dorsal surface smooth, ventral surface armed with two rows of spines increasing in size distally; fore and middle tibiae sub-cylindrical, unarmed, sulcate; inner and outer surface of hind tibiae markedly dilated; outer surface smooth, inner surface with short tubercles on the border.

Scutellum. Triangular, longer than wide, transversely striate, punctate; apex subacute.

Abdomen. Posterior angle of abdominal segments III to VII armed with short but distinct spine.

Male. Unknown.

Measurements (holotype; mm). Total body length 25.75. Head length 1.90; width across eyes 2.59; interocular space 1.55 ; interocellar space 0.77 ; preocular distance 1.38; length of antennal segments: I, 5.77; II, 4.10; III, 4.25; IV, 6.84. Pronotal length 5.74; width across humeral angles 8.76. Scutellar length 3.66; width 3.37 . Maximum width of abdomen 9.73.

Differential diagnosis. Like M. phyllocnemis and $M$. quadrivittis, the humeral angles of $M$. perampla sp.nov., are prominent, laterally expanded and apically blunt; the pronotal disk has four longitudinal dark brown lines with the midline unpigmented; total body length over $20 \mathrm{~mm}$. Melucha perampla differs by having the antennal segments I to III black, antennal segment III clearly dilated at inner and outer faces and mesopleura and metapleura without black marks. In the other two species the antennal segments I to III are yellowish orange, antennal segment III is almost cylidrical, not dilated and mesopleura and metapleura have reddish brown to black elongate marks. The dorsal surface of the hind femur of $M$. quadrivittis is armed with two rows of black nodules and tubercles (Fig. 8) while in M. phyllocnemis and M. perampla those are smooth (Figs. 9, 12).

Etymology. Named for the large size of this species, after the Latin adjective "peramplus, -a,-um", meaning very large.

Distribution. Known from Bolivia and Paraguay.

\section{Melucha lineatella (Fabricius, 1803)}

http://species-id.net/wiki/Melucha_grandicula Fig. 6.

Lygaeus lineatellus Fabricius, 1803: 216.

Melucha ruficornis Breddin, 1903: 379-380, syn. n.

Type material examined. Melucha ruficornis: female, Bolivia, La Paz, Yungas (DEIC).

Taxonomy. Melucha ruficornis Breddin, 1903, was described based on a single female from Bolivia and here is considered a junior synonym of $M$. lineatella (Fabricius, 1803). The holotype of $M$. ruficornis was examined and compared with several specimens of Melucha lineatella. The features considered by Breddin as diagnostic characters like the total length of the body, the shape of the humeral angles, and the color of antennal segments, pronotal disk and hind femora are shared with $M$. lineatella and this reinforces the proposed synonymy. 


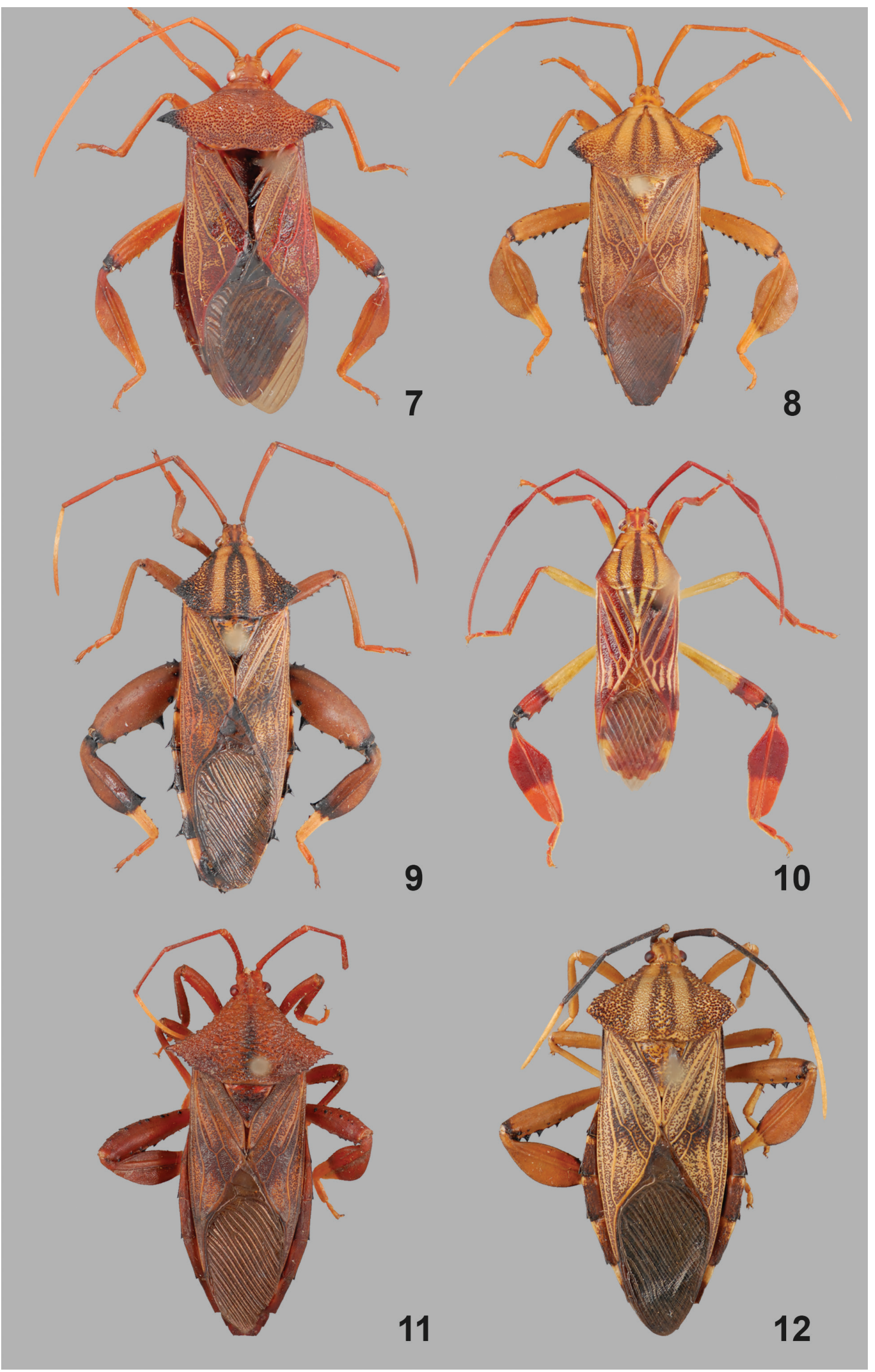

Figures 7-12. Dorsal view of Melucha spp. 7, M. gladiator (Fabricius, 1803) (female). 8, M. quadrivittis Stål, 1862 (female). 9, M. phyllocnemis (Burmeister, 1835) (male). 10, M. quinquelineata Stål, 1865 (male). 11, M. grandicula sp. n. (female). 12, M. perampla sp. n. (female). 


\section{Melucha phyllocnemis (Burmeister, 1835)}

http://species-id.net/wiki/Melucha_phyllocnemis Fig. 9.

Cerbus phyllocnemis Burmesiter, 1835: 340

Distribution. Bolivia: Coroico Yungas. Brazil: Sao Paulo, Rio de Janeiro, Rio Grande do Sul. Colombia: Nova Granada (Stål 1870). Paraguay (Stål 1870, Blöte 1938, Osborn 1904, Packauskas 2010).

Material examined. New records. Argentina: 2 males, Misiones, Posadas, VII-1972, D. Carpintero (UNAM); 3 females, Misiones, Iguazu, III-1954, III1981, 14-XI-1981, A. Martinez, R. Foerster (MABR, UNAM); 1 male, Entre Rios, I-1974, Zelich (UNAM); 1 male, Formosa Estancia, Guaycolec, 25 km N Formosa, 185 m, 26-II-10-III-1999, S. L. Heydon, J. Ledford (UCDC). Brazil: 1 female, Espiritu Santo, Santa Teresa, 18-23-XII-1967, C. Elias (UNAM); 1 female, Nova Teutonia, 17-XII-1935, F. Plaumann (USNM). Paraguay: 1 male, District Villarrica, Mbebo, XI-1926, P. Jorgensen (ZMUH); 1 female, San Pedro, General Resquin, Naranjito, 1-I-1994, B. Garcete (MELN); 1 female, Depto. San Pedro, Coroño, Rio Ypane, 12-XI-1983, G. Willner (CDFA); 1 male, Depto. San Pedro, Coroño, 1-30-X1979, G. J. Willner (CDFA).

\section{Melucha quadrivittis Stål, 1862}

http://species-id.net/wiki/Melucha_quadrivittis

Fig. 8 .

Melucha quadrivittis Stål, 1862: 276, stat. restit.

Melucha quadrivittis: Stål, 1870: 133 (synonymized with $M$. phyllocnemis)

Type material examined. Melucha quadrivittis: male (NHRS).

Distribution. Mexico, Oaxaca, Veracruz, Atoyac and Orizaba (Stål 1862, Walker 1871, Distant 1893, Packauskas 2010).

Material examined. New records. Belize: 1 female, Grano de Oro, Chiquibul Forest Reserve, 4-7-IV-1995, T. King, A. Howe (UNAM). Costa Rica: 4 males, 4 females, Provincia Guanacaste, estacion Las pailas, P. N. Rincon de la Vieja, 800 m, 27-VII-12-X-1992, 15-V-11-VI-1993, 8-26-V-1994, C. Cano, D. Garcia, K. E. Taylor (INBIO); 3 males, 3 females, Provincia Guanacaste, Estacion Santa Rosa, P. N. Santa Rosa, 300 m, VIII-1980, VII-1989, II-1992, (without collector) (INBIO); 5 females, Provincia Puntarenas, Fca. Cafrosa, Estacion Las Mellizas, P. N. Amistad, 1300 m, X-1989, 7-XII-1989, 17-I-1990, M. Ramirez, G. Mora (INBIO). Honduras: 1 male, Liberia, 6-IX-1984, C. W. O'Brien (UNAM); 1 female, Olancho, La Muralla, 24-V-1995, R. Morris (UGAG); 1 male, Copan, 19 km SW Santa Rosa de Copan, 8-X-1993, R. Turnbow (UGAG); 1 female, Cedros, Francisco Morazan, 2-XII1976 (UMSP). Mexico: 1 female, Campeche, 6 mi N de
Xpujil, Chicana Ruins, 27-VII-1980, Schaffner, Weaber (TAMU); 1 male, 13.8 mi E Escarcega, 26-27-VII1980, Schaffner, Weaber (TAMU). 1 female, Chiapas, 2 mi E Rizo de Oro, 2900', 1-VIII-1974, C. W. and L. O'Brien and Marshall (UNAM); 2 males, Chiapas, Municipio de Ocozocoautla, Reserva El Ocote, $2 \mathrm{~km}$ de A. Obregon, 14-IV-1994, O. Gomez (UNAM); 1 female, Chiapas, Bonampak, 21-V-1980, J. Bueno (UNAM); 1 female, Chiapas, Reserva El Ocote, 2-10-XII-1993, G. Ortega-Leon, E. Barrera and A. Casasola (UNAM); 1 male, Chiapas, Villa Corzo, 2-XI-1983, J. Morales (UNAM); 1 male, Nuevo Leon, Guadalupe, X-1980, A. Ortiz (UNAM); 2 females, Nuevo Leon, Rayones, 17-IV-1974, Patton (UNAM); 1 female, Oaxaca, Tuxtepec, 24-IX-1947 (UNAM); 1 male, Oaxaca, 2 mi N Candelaria Loxicha, 17-VII-1974, Clark, Schaffner (TAMU); 2 males, 1 female, Quintana Roo, X-Can Nuevo, 17-IX-1983, E. Welling (UNAM); 1 female, Quintana Roo, 8 mi N Felipe Carrillo Puerto, 1-VII-1970, R. E. Beer (UNAM); 1 female, Quintana Roo, 26 km SE Valle Hermoso, 22-VI-1989, A. Cadena, L. Cervantes (UNAM); 1 male, Quintana Roo, 3-VIII-1981, E. Pech (UNAM); 1 female, Quintana Roo, 2 km NE El Ramonal, 10-IX-1983, O. Canul (UNAM); 1 female, Quintana Roo, Puerto Morelos, 11-VIII-1982, V. Hernandez (UNAM); 1 female, San Luis Potosi, El Salto, IX-1959, D. Pelaez (UNAM). 1 male, Tabasco, Campo Experimental CSAT, Cardenas, 13-IX-1976, J. Rivera (UNAM). 1 male, 1 female, Tamaulipas, Ciudad Victoria, 17-XI-1977, H. Brailovsky (UNAM); 1 male, Tamaulipas, Tula, km 20 Tula-Ocampo, Colonia Guadalupe, 446 m, 22 53'13'N-99²8'34'W, 12-V-2007, H. Brailovsky, E. Barrera and L. Cervantes-Peredo (UNAM). 7 males, 7 females, Veracruz, Estación de Biología Tropical Los Tuxtlas, III-1978, 20-XII-1984, 25-VIII-1998, 27-X-4-XI-1988，15-27-VI-1989，21-VII-1989，6-IX1989, 30-X-2007, H. Brailovsky, E. Gonzalez, E. Mejorada, H. Rojas, J. L. Colin and R. Mariño (UNAM). Nicaragua: 1 male, Chinaniloga, Volcan Casita, 10-VI1985, Maes, Jolivet (MELN); 1 female, Matagalpa, Selva Negra, 1375 m, 28-XII-1991, A. E. Mahler (UNAM). Panama: 1 male, Chiriqui, Chiriquicito, 16-V-1996, R. Turnbow (UGAG); 1 male, Panama Prov., Cerro Campana, 11-IX-1998, Gillogly, Stockwell (TAMU).

Taxonomy. Burmeister (1835) described M. phyllocnemis from Brazil, and Stål (1862) M. quadrivittis from Mexico. Dallas (1852) recorded M. phyllocnemis from Colombia and years later Stål (1870) synonymized $M$. quadrivittis under $M$. phyllocnemis and recorded this species from Mexico, Colombia (Nova Granada), Brazil and Paraguay. Packauskas (2010) summarized the known information and cited M. phyllocnemis s. lato from Bolivia, Brazil, Mexico, Colombia and Paraguay. The type material of $M$. quadrivittis was examined and compared with the original description of $M$. phyllocnemis, as well as with more than 110 specimens. Two different species were clearly recognized, therefore $M$. quadrivittis was resurrected here as valid species. 
Both species share the following characters: total body length over $23.00 \mathrm{~mm}$; anterolateral borders of pronotum coarsely serrate; pronotal disk yellow with four longitudinal dark lines; the humeral angles prominent, laterally expanded; and antennal segments II and III pale orange to yellowish orange.
In $M$. quadrivittis the dorsal surface of hind femur is armed with two rows of black nodules and tubercles; it is distributed from Mexico to Panama (Fig. 8). In M. phyllocnemis the dorsal surface of hind femur is smooth. It is distributed from Colombia to Paraguay, including Bolivia and Brazil (Fig. 9).

\section{Key to the known species of Melucha Amyot \& Serville, 1843}

1 Anterolateral borders of pronotum very coarsely serrate; total length of body longer than $23.00 \mathrm{~mm} \ldots \ldots \ldots \ldots \ldots \ldots \ldots . . . \ldots \ldots$

- Anterolateral borders of pronotum smooth or finely serrate; total length of body shorter than $20.00 \mathrm{~mm} \ldots \ldots \ldots \ldots \ldots \ldots$

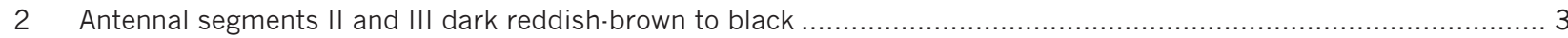

- Antennal segments II and III pale orange to pale yellowish orange............................................................... 4

3 Pronotal disk dark reddish-brown; dorsal surface of hind femora dark reddish- brown and ventral surface dull orange..

M. bicolor Distant, 1892

- Pronotal disk yellow with four longitudinal dark brown lines; hind femora yellow with ventral spines black (Fig. 12)......

M. perampla sp. n.

4 Pronotal disk reddish-brown, with a single longitudinal median dark line; humeral angles of pronotum prominent, laterally expanded, and apically sharply pointed (Fig. 11) ........................................................... grandicula sp. n.

- Pronotal disk yellow with four longitudinal dark lines; humeral angles of pronotum prominent, laterally expanded, and

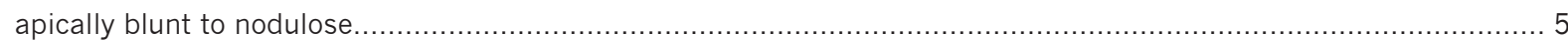

5 Dorsal surface of hind femur armed with two rows of black nodules and tubercles (Fig. 8) ...... M. quadrivittis Stål, 1862

- Dorsal surface of hind femur smooth (Fig. 9)

6 Anterolateral borders of pronotum uniformly crenulate; humeral angles laterally expanded, apically sharply pointed.. 7

- Anterolateral borders of pronotum smooth; humeral angles obtuse, not exposed, with or without short spine directed backward. 10

7 Antennal segments I to III entirely shiny orange; anterolateral borders of pronotum shiny orange (Fig. 7)..... M. gladiator (Fabricius, 1803)

- Antennal segments I to III predominantly or entirely black or dark reddish brown; anterolateral borders of pronotum black

8 Antennal segment IV dark brown with basal third (except basal joint) yellow (Fig. 1) ........... aculeata Montandon, 1895

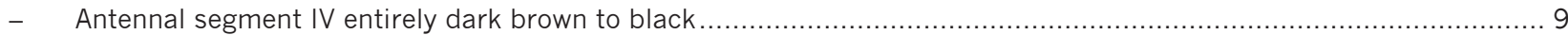

9 Hemelytral membrane brassy with basal third black; antennal segment III bicolorous (Fig. 2) .. M. biolleyi Distant, 1900

- Hemelytral membrane uniformly brassy, without black spot basally; antennal segment III entirely black (Fig. 4) ..........

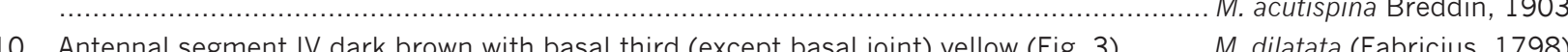

- Antennal segment IV entirely dark brown or dark reddish brown or shiny reddish orange ................................... 11

11 Antennal segments I to III shiny orange to shiny reddish brown; pronotal disk shiny yellow with three black to red. dish-bown longitudinal stripes (Fig. 10) ............................................................. quinquelineata Stål, 1865

- Antennal segments I to III never shiny orange; pronotal disk yellow with one black to reddish brown longitudinal stripe running mesially......

12 Antennal segments II and III reddish-brown with basal joint yellow (Fig. 5)

M. chapadana Brailovsky, 1993

- $\quad$ Antennal segments II and III entirely reddish-brown (Fig. 6) M. lineatella (Fabricius, 1798)

\section{Acknowledgments}

We thank R. T. Schuh (AMNH), R: Garrison (CDFA), Stephan M. Blank (DEIC), Jesus Ugalde (INBIO), Diego Carpintero (MABR), J. M. Maes (MELN), Gunvi Lindberg (NHRS), H. Zettel (NHMW), J. C. Schaffner (TAMU), Cecil L. Smith (UGAG), P. J. Clausen (UMSP), T. J. Henry (USNM), and H. Strümpel (ZMUH) for the loan of specimens and other assitance.

\section{References}

Amyot CJB, Serville A (1843) Histoire naturelle des insectes. Hémiptères. In: "Studies à Buffon." Fain at Thunot. Paris. LXXVI, 675 pp.

Blöte HC (1938) Catalogue of the Coreidae in the Rijksmuseum van Natuurlijke Histoire. Part IV. Coreinae, third part. Zoologische Mededeelingen 20: 75-308.

Brailovsky H (1993) Género nuevo y especies nuevas de coreidos neotropicales (Hemiptera-Heteroptera-Coreidae: Acanthocerini, Chari- 
esterini, Coreini, Discogastrini, Leptoscelidini y Nematopodini). Anales del Instituto de Biología, Universidad Nacional Autónoma de México, Serie Zoología 64(2): 109-127.

Breddin G (1903) Beiträge zur Hemipteran fauna der Anden. Sitzung berichte der Gesellschaft Naturforschender Freunde zu Berlin 8: 366-383.

Burmeister H (1835) Handbuch der Entomologie. Zweiter Band. Besondere Entomologie. I. Ordnung. Rhynchota. T. Enslin., Berlin, Abtheil I, 400 pp.

Distant WL (1881-1893) Insecta Rhynchota. Hemiptera-Heteroptera. Vol. I. III. Biologia Centrali-Americana, London, 462 pp.

Fabricius JC (1803) Systema Rhyngotorum secundum ordines, genera, species, adjectis synonymis, locis, observationibus, descriptionibus. Apud Carolum Reichard, Brunsvigae, 314 pp. doi: 10.5962/bhl.title.11644
Osborn H (1904) Notes on South American Hemiptera-Heteroptera. Ohio Naturalist 5: 195-204

O'Shea R (1980) A generic revision of the Nematopodini (Heteroptera: Coreidae: Coreinae). Studies on Neotropical Fauna and Environment 15: 197-225. doi: 10.1080/01650528009360574

Packauskas R (2010) Catalog of the Coreidae, or leaf-footed bugs of the New World. Fort Hays Studies, Fourth Series, 5: 1-270.

Stål C (1862) Hemiptera mexicana enumeravit speciesque novas descripsit. Stettin Entomologische Zeitung 23(4-6): 273-281.

Stål C (1870) Enumeratio Hemipterorum. Kongliga Svenska Vetenskaps-Akademiens Förhandlingar, part 1, 9: 1-232.

Walker F (1871) Catalogue of the specimens of Hemiptera-Heteroptera in the collection of the British Museum, Part 4, London: 1-211. 